\title{
Successful Medical Treatment of Segmental Dilatation of Duodenal Bulb in an Infant
}

\author{
Bir Süt Çocuğunda Duodenal Bulbusun Segmentel Dilatasyonunun Bașarılı Medikal Tedavisi
}

\author{
Banu Aydın', Dilek Dilli', Selim Gökçe'², Serdar Beken'1, Ayșegül Zenciroğlu', Nurullah Okumuș' \\ ${ }^{I}$ Department of Neonatology, Dr. Sami Ulus Maternity and Children's Health and Diseases Training and Research Hospital, Ankara, Turkey; \\ ${ }^{2}$ Department of Pediatric Gastroenterology, Dr. Sami Ulus Maternity and Children's Health and Diseases Training and Research Hospital, \\ Ankara, Turkey
}

\begin{abstract}
Vomiting of infants may result from an inefficaciously functioning gastroesophageal junction or it may be associated with numerous serious diseases. Segmental bulbus dilatation of duodenum is a very rare gastrointestinal system pathology that can trigger vomiting by causing either motility disorder or gastroesophageal reflux. In the case here presented, endoscopic examination showed a severely dilated bulbus duodeni with decreased motility. In contrast with the previous cases reported in literature, the condition was treated medically with success.
\end{abstract}

Key words: dilatation; duodenum; endoscopy; gastrointestinal; infant; newborn

\section{ÖZET}

Infantlarda kusma birçok hastalığın seyri sırasında ya da gastroösefageal bileșkenin yetersizliği sonucu ortaya çıkabilir. Segmental bulbus dilatasyonu çok nadir görülen bir gastrointestinal sistem patolojisidir ve motilite bozukluğu yaparak veya gastroösefageal reflüye yol açarak kusmayı tetikleyebilir. Bu yazıda; yenidoğan döneminde inatçı kusmaları bașlayan ve endoskopi ile motilite azalmasına neden olan bir segmental duodenal bulbus dilatasyonlu olgu sunulmuștur. Literatürde bildirilmiș diğer olgulardan farklı olarak, bu durum bașarı ile tedavi edilmiștir.

Anahtar kelimeler: dilatasyon; duodenum; endoskopi; gastroentestinal; süt çocuğu; yenidoğan

\section{Introduction}

Vomiting is a common symptom of many diseases of infants. Although mild vomiting which takes the form of regurgitation in infants is a benign condition, refractory vomiting may be an alarming symptom of a series disease.

Vomiting is common during gastrointestinal problems including nutritional disorders, food allergies, gastroenteritis, gastritis, eosinophilic esophagitis, achalasia and gastroesophageal reflux. In addition gastrointestinal system (GIS) obstructions such as pyloric stenosis, duodenal obstruction, malrotation, volvulus and Hirschsprung's disease; neurological disorders like hydrocephalus and mass lesions; inflammations such as meningitis, sepsis and urinary tract infections; metabolic disorders and endocrine diseases such as urea cycle defect, galactosemia, organic acidemia, congenital adrenal hyperplasia, and hypercalcemia ${ }^{1-3}$ may be associated with vomiting.

Segmental bulbus dilatation is a very rare GIS pathology and it can trigger vomiting by causing motility disorders or gastroesophageal reflux. Until today, four cases with segmental bulbus dilatation have been reported. In this article, we report a case of segmental bulbus dilatation of an infant presenting with vomiting refractory to treatment and diagnosed by upper GIS endoscopy.

\section{Case Report}

Our patient was an infant girl and admitted to hospital as a result of refractory vomiting at the postnatal 111 th day. 
The pregnancy of the mother of the infant had been under medical supervision. The mother had received vitamin and iron supplementation. Her previous pregnancy that resulted with the birth of a girl, now she was four years old, had been uneventful.

She was born by caesarean section at 35 weeks of the pregnancy as one of the triplets from a healthy 34 year-old mother and a healthy 30 year-old father. Her birth weight was 1500 grams. She could receive full enteral feeding at the end of $3 \mathrm{rd}$ postnatal week without consequent complications. She was discharged in the sixth postnatal week and fed with formula at home.

She was hospitalized soon again as she vomited large amounts of undigested food following each feeding. Other two males of the triplet pregnancy were fine and fed on baby formula. However, they did not vomit and their weights were appreciated for date.

The initial physical examination of the patient revealed findings of body temperature: $36.4^{\circ} \mathrm{C}$, heart rate: $138 /$ $\min$, respiratory rate: $48 / \mathrm{min}$, body weight: $1980 \mathrm{~g}$ ( $<5$ th percentile), height: $44 \mathrm{~cm}(<5$ th percentile) and head circumference: $35 \mathrm{~cm}$ ( $<5$ th percentile). In addition the baby had atopic dermatitis.

The findings of the laboratory investigation were as follows: hemoglobin: $8 \mathrm{~g} / \mathrm{dl}$, hematocrit: $23 \%$, leukocyte: $9750 / \mathrm{mm}^{3}$, thrombocyte: $406000 / \mathrm{mm}^{3}$, MCV: $74 \mathrm{fL}$, $\mathrm{MCH}: 25 \mathrm{pg}$. The measurement of values of electrolytes, liver and kidney tests revealed results within normal ranges. The results of the venous blood gas analysis were as: $\mathrm{pH}: 7.32, \mathrm{HCO}_{3}: 14 \mathrm{mmol} / \mathrm{L}$. Complete urinalyses revealed a $\mathrm{pH}$ of 6.5 and a density of 1020 . Tests to isolate possible infections and abdominal X-ray examination did not reveal any pathological finding.

Although the infant was eager for oral feeding, even the smallest amount of food was vomited. The vomit did not contain any bile.

Metabolic tests including blood and urine amino acids, tandem mass spectrometry, biotinidase activity, ammonia levels and urine organic acids were unremarkable. We gave a completely hydrolyzed baby formula in order to eliminate cow's milk allergy. However, milk-specific and casein-specific IgE score was 0 and the vomiting continued despite the amino acid-based formula.

Abdominal ultrasound (USG) did not reveal any evidence of pyloric stenosis. Upper gastrointestinal series showed gastroesophageal reflux, thus the baby was put on sodium-magnesium alginate (orally $4 \mathrm{X} 0.1 \mathrm{cc} / \mathrm{kg} /$ dose) therapy.
On the 15th day following hospitalization, we performed an upper GIS endoscopic examination. The esophagus and the stomach were normal, and the pyloric configuration was also normal. However, the duodenal bulbus was dilated and hypokinetic (Figure 1). In contrast, the second and third portions of the duodenum were normal.

We began oral feeding once again with an anti-reflux baby formula containing locust bean gum and started oral domperidone $0.1 \mathrm{ml} / \mathrm{kg}$ per feeding. Consequently, vomiting ceased. Upper GIS endoscopy repeated on the 38th day following the hospitalization showed a reduction in the size of the dilated segment and the duodenal motility improved (Figure 2). The patient reached $2700 \mathrm{~g}$ and was discharged with domperidone and sodium-magnesium alginate treatment. During the latest follow-up visit when she was at 9 months, her growth and development were consistent with her peers. Her weight, height and head circumference were within the 25 th-50th percentiles.

\section{Discussion}

Vomiting is the involuntary expulsion of the contents of the stomach through the mouth and/or the nose. In infants, vomiting may result from an inefficaciously functioning gastroesophageal junction or may be a

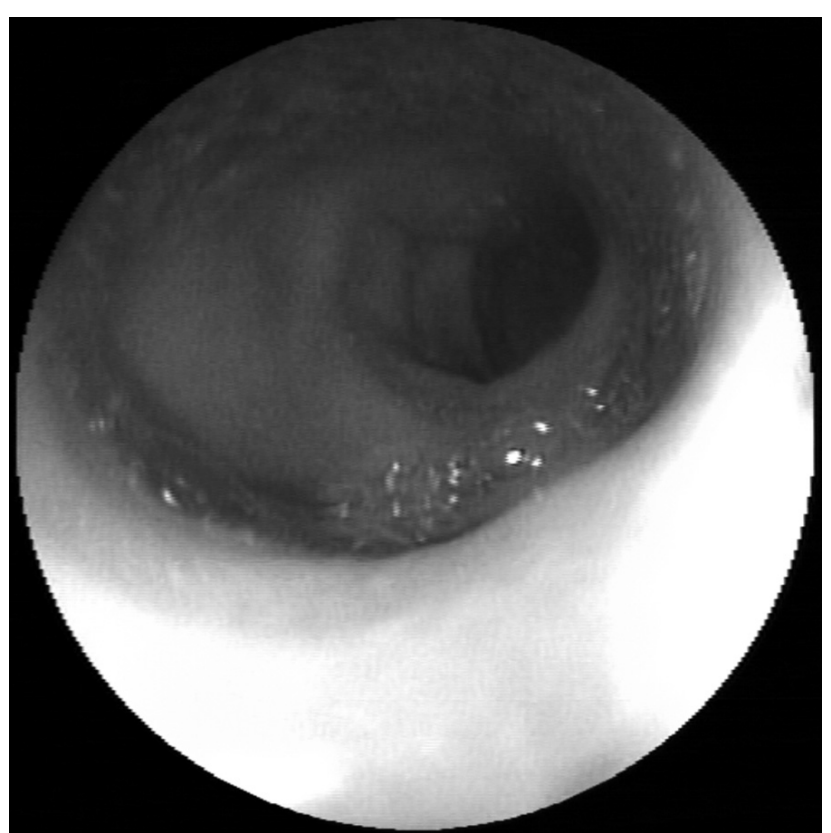

Figure 1. The dilated duedenal bulb of the infant demonstrated by using endoscopy. 


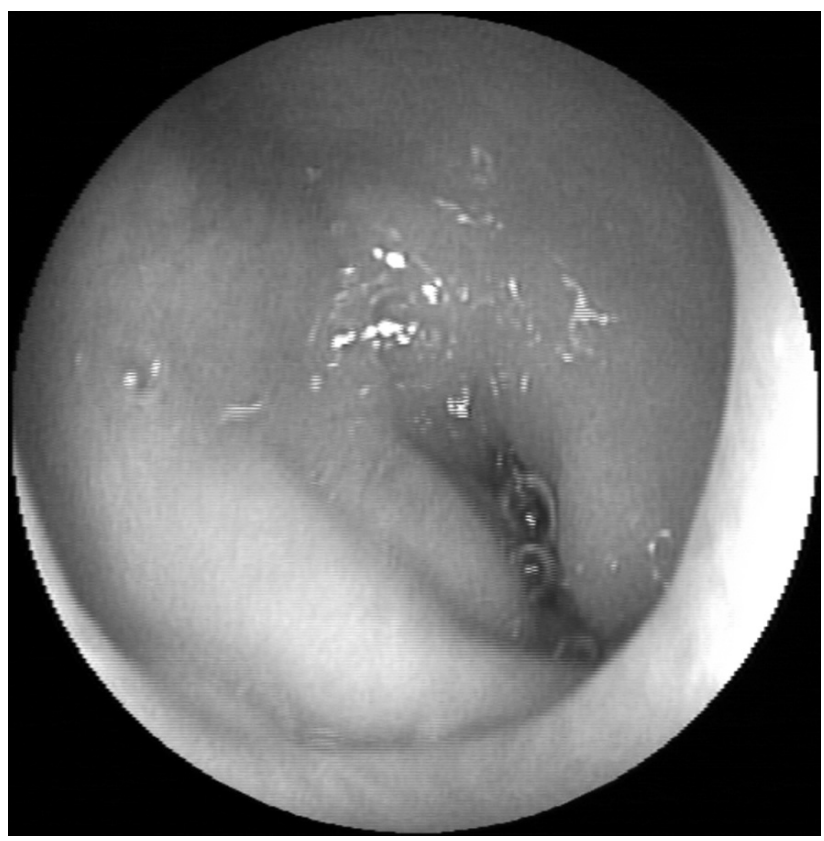

Figure 2. The image of the duedenal bulb following treatment.

symptom that forewarns of numerous serious diseases. The most common reason of newborn vomiting is feeding errors, such as overfeeding, insufficient releasing of gas, and feeding with foods that the baby is not mature enough to digest ${ }^{4}$. At first sight our case was also considered as premature for digesting full oral feeding, because she was one of the triplets delivered at 35 th week of the pregnancy.

Vomiting can also result from anomalies/obstructions in the gastrointestinal system. The most common of these conditions are pyloric stenosis, malrotation, duodenal obstruction, and volvulus ${ }^{5,6}$. These conditions can easily be detected through imaging methods such as abdominal X-ray and USG. However, none of these imaging methods revealed the pathological finding in our case. Fortunately we could diagnose the segmental bulbus dilatation using GIS endoscopy.

To our knowledge, until today, only a few cases with segmental bulbus dilatation have been reported in medical literature. Rovira et al. were the first to report two cases male of idiopathic segmental dilatation of the duodenum in $1989^{7}$. Both patients underwent duodenal resection and one of them died soon after surgery. According to the pathological examination, his duodenal layers were normal. The other patient recovered, but he was diagnosed with vascular dysplasia.
Cuming et al. reported an infant with an intra-abdominal cyst in the antenatal 17 th $^{\text {week }}{ }^{8}$. After birth segmental bulbus dilatation was demonstrated through laparotomy and the lesion was removed. Inoue et al. reported a similar case and the infant was dead because of severe pulmonary hypertension?. Lastly, in 2011 Katsura et al. reported a similar case discovered in the antenatal period. There was an intra-abdominal cyst and the postnatal diagnosis was segmental bulbus dilatation ${ }^{10}$. The newborn was cured by partial resection. All of the published four cases were treated surgically. In contrast our case was treated medically.

We infer from the case that pressure in the stomach probably increases secondary to the dilatation of the bulbus and it triggers gastroesophageal reflux. The detection of reflux and the treatment with an anti-reflux baby formula, a prokinetic agent (domperidone) and a medical treatment intended to protect the gastric mucosa (sodium alginate and lansoprazole) support the explanation. Even though it is a very rare condition, segmental bulbus dilatation should also be considered in cases of refractory vomiting of infancy.

\section{References}

1. Ben Salem A, Zrig H, Hafsa C. Vomiting newborn. Arch Pediatr 2011;18:1110-1.

2. Blanco FC, Davenport KP, Kane TD. Pediatric gastroesophageal reflux disease. Surg Clin North Am 2012;92:541-58.

3. Juang D, Snyder CL. Neonatal bowel obstruction. Surg Clin North Am 2012;92:685-711.

4. Fleisher DR. Functional vomiting disorders in infancy: innocent vomiting, nervous vomiting, and infant rumination syndrome. J Pediatr 1994;125:84-94.

5. Hernanz-Schulman M. Infantile hypertrophic pyloric stenosis. Radiology 2003;227:319-31.

6. Palmas G, Maxia L, Fanos V. Volvulus and intestinal malrotation in the newborn. Pediatr Med Chir 2005;27:62-6.

7. Rovira J, Morales L, Parri FJ, et al. Segmental dilatation of the duodenum. J Pediatr Surg 1989;24:1155-7.

8. Cuming $\mathrm{T}$, Asif $\mathrm{M}, \mathrm{Babu} \mathrm{R}$, et al. Congenital segmental dilatation of the duodenum - differential diagnosis for an antenatally-diagnosed intra-abdominal cyst. Eur J Pediatr Surg 2001;11:133-5.

9. Inoue $\mathrm{M}$, Uchida $\mathrm{K}$, Otake $\mathrm{K}$, et al. Congenital segmental dilatation of the duodenum: Report of a case. Pediatr Int 2010;52: e184-6.

10. Katsura S, Kudo T, Enoki T, et al. Congenital segmental dilatation of the duodenum: report of a case. Surg Today 2011;41:4. 